\title{
De daling in jeugddelinquentie: minder risico, meer bescherming?
}

\author{
André van der Laan, Josja Rokven, Gijs Weijters \& Marinus Beerthuizen
}

Volgens politiestatistieken daalt de Nederlandse jeugdcriminaliteit na 2007 jaarlijks. Verklaringen voor de daling richten zich vooral op veranderingen in macrofactoren, zoals toegenomen welvaart, meer gerichte inzet van politie, of daling in alcoholgebruik. Ook de prevalentie van zelfgerapporteerde jeugddelinquentie laat een afname zien in de periode 2005-2015. In drie opeenvolgende cohorten van de Monitor Zelfgerapporteerde Jeugdcriminaliteit (2005, 2010 en 2015) blijken veranderingen in risico- en beschermende factoren bij 12- tot 18-jarigen een mogelijke verklaring te bieden voor de daling in prevalentie van delinquentie. Jongeren uit het 2015-cohort geven aan minder blootgesteld te worden aan risicofactoren voor jeugddelinquentie, zoals alcoholgebruik en delinquente vrienden, terwijl ze ook meer beschermende opvoedingsfactoren rapporteren, zoals ervaren emotionele steun, betrokkenheid en monitoring door ouders, dan jongeren uit eerdere cohorten. Onder ernstig delinquente jongeren is de blootstelling aan individueel risicogedrag en delinquente vrienden stabiel over de tijd. Dit gaat bij deze groep gepaard met stabiliteit in de frequentie en zwaarte van gerapporteerde delicten over de drie cohorten. De gevoeligheid voor risico- en beschermende factoren blijkt consistent over de cohorten, ongeacht de ernst van delinquentie. Dit lijkt te wijzen op een veranderende sociaal-culturele houding ten aanzien van risicogedrag, waaronder delinquentie, wat een aanvullende verklaring kan bieden voor de daling in de jeugdcriminaliteit. Implicaties voor theorie en beleid worden besproken.

\section{Inleiding}

In Nederland daalt de door politie geregistreerde jeugdcriminaliteit na 2007 jaarlijks. Het aandeel minderjarige verdachten in 2014 is met 64 procent afgenomen ten opzichte van 2007. De sterkte van de afname verschilt als wordt uitgesplitst naar type delicten of sociaal-demografische achtergronden (sekse, herkomst, regio, gezinskenmerken, opleidingsniveau), maar de algemene trend is dat het aandeel jeugdige verdachten afneemt. Ook als jongeren zelf worden bevraagd, blijkt een daling in het percentage zelfgerapporteerde daders in de periode 2005-2015, enkele uitzonderingen daargelaten. Het percentage verdachten daalt sterker dan het percentage jongeren dat in zelfrapportage een delict rapporteert, wat mogelijk wijst op een verschil in de sterkte van de daling naar ernst van delinquentie (Van der Laan \& Goudriaan, 2016).

Internationaal laat de geregistreerde jeugdcriminaliteit ook een daling zien (Berghuis \& De Waard, 2017; Eurostat, 2016). Deze daling staat niet op zichzelf. In de westerse wereld, zowel in Noord-Amerika en Europa als in Australië en Azië, is al sinds de jaren negentig van de vorige eeuw sprake van een 'crime drop' die verder 
reikt dan alleen jeugdcriminaliteit, hoewel de 'timing' van het moment waarop de daling inzette wel verschilt per land (Tonry, 2014). ${ }^{1}$

In de literatuur is geen overeenstemming over de vraag waarom de criminaliteit daalt. Er kan een onderscheid worden gemaakt tussen verklaringen die stellen dat er een enkele (maatschappelijke) ontwikkeling ten grondslag ligt aan de daling en verklaringen die uitgaan van het gelijktijdig optreden van meerdere ontwikkelingen. ${ }^{2}$ Bij het eerste type verklaringen wordt aangenomen dat als de algemene daling in de criminaliteit in meerdere landen min of meer gelijktijdig is ingezet, dit alleen kan worden verklaard door één maatschappelijke ontwikkeling die in al die landen in min of meer dezelfde periode plaatsvindt. Zo constateren Farrell e.a. (2014) dat één verklaring algemene geldigheid geniet voor de daling, namelijk de 'security'-hypothese (Van Dijk e.a., 2012). Volgens hen wordt de internationale 'crime drop' sinds het begin van de jaren negentig verklaard door de toegenomen situationele beveiliging, uiteenlopend van het beter beveiligen van woningen en auto's tot cameratoezicht. Ook is geopperd dat de digitalisering van de samenleving (internetgebruik, social media of computergames) de recente daling in (jeugd)criminaliteit kan verklaren vanwege veranderende vrijetijdsbestedingen (Beerthuizen e.a., 2017; Farrell e.a., 2014; Weerman, 2017). Zo beargumenteert Weerman (2017) dat de opkomst van social media ertoe heeft geleid dat de vrijetijdsbesteding van jongeren is verschoven van de straat naar de online wereld. Deze veranderende vrijetijdsbesteding kan ertoe hebben bijgedragen dat steeds meer jongeren ervan worden weerhouden om delicten te plegen. ${ }^{3}$

Anderen stellen dat er niet een enkele maatschappelijke ontwikkeling kan worden aangewezen die verantwoordelijk is voor de afname in de criminaliteit, maar dat de daling het resultaat is van meerdere min of meer gelijktijdig optredende ontwikkelingen (Levitt, 2004; Roeder e.a., 2015; Tonry, 2014; Zimring, 2007). Mogelijke verklaringen voor de recente daling in criminaliteit betreffen veranderingen in rechtshandhaving, zoals een toename van politie-inzet op straat (Vollaard \& Koning, 2009) of veranderingen in politiestrategieën door toenemende aandacht voor hotspots of hotgroups (Braga \& Weisburd, 2010; Roeder e.a., 2015). Ook demografische, sociale en economische ontwikkelingen worden genoemd als mogelijke verklaring voor de daling. Het betreft bijvoorbeeld een toename van het

1 Het betreft de ontwikkelingen in de afgelopen drie decennia. Vanuit historisch perspectief is al veel langer sprake van een daling in de criminaliteit. Zo laat bijvoorbeeld Eisner (2014) overtuigend zien dat de moordratio in westerse landen al sinds de middeleeuwen afneemt.

2 Tonry (2014) onderscheidt simpele en complexe verklaringen. Simpele verklaringen betreffen ontwikkelingen die betrekking hebben op seculiere veranderingen die zich in een specifieke periode voordoen op een bepaald domein, zoals toegenomen beveiliging. Complexe verklaringen betreffen interacties tussen culturele en seculiere ontwikkelingen, die vervolgens ook weer effect hebben op sociale controle en individuele zelfcontrole. Volgens deze verklaringen is er sprake van interactie tussen micro- en macro-ontwikkelingen.

3 Ook is geopperd dat er misschien sprake is van een verplaatsing van delinquent gedrag van de offline wereld naar de virtuele wereld. Mogelijk is sprake van een daling in de traditionele offline gepleegde criminaliteit, maar neemt cybercriminaliteit toe (Tcherni e.a., 2016). Empirisch onderzoek naar verplaatsingseffecten van criminaliteit naar de virtuele wereld staat echter nog in de kinderschoenen en biedt tot nog toe nauwelijks aanwijzingen voor een verplaatsing van jeugddelinquentie (Rokven e.a., 2017). 
aantal jongeren dat een opleiding afrondt (Lochner \& Moretti, 2004), een toename van lonen bij laagopgeleide mannen (Gould e.a., 2002), de toegenomen welvaart of een afname in alcoholconsumptie (Roeder e.a., 2015). Kortom, in de (inter)nationale literatuur wordt erop gewezen dat de recente daling in de criminaliteit een resultaat lijkt te zijn van het gelijktijdig optreden van meerdere maatschappelijke ontwikkelingen. Daarbij betreft het beleidsmatige, demografische, sociale en economische ontwikkelingen alsook de digitalisering.

Deze macroverklaringen hebben overwegend betrekking op criminaliteit in het algemeen. Of de factoren ook bijdragen aan de daling in jeugdcriminaliteit is minder duidelijk. Ten eerste is empirisch onderzoek naar verklaringen voor ontwikkelingen in jeugdcriminaliteit schaars (Van der Laan \& Weijters, 2015; Roth e.a., 2012). Ten tweede is het de vraag of, en in hoeverre, veranderingen die zich op maatschappelijk niveau voordoen ook doorwerken op individueel gedrag van jeugdigen. Maatschappelijke ontwikkelingen kunnen alleen effect hebben op individueel gedrag als dat gaat via factoren die direct effect hebben op dat individuele gedrag (Coleman, 1990). Individuele, gezins- en bredere contextkenmerken (vrienden, school) hebben een meer direct effect op delinquentie dan maatschappelijke ontwikkelingen (Tanner-Smith e.a., 2013). Hierbij is sprake van een wisselwerking. Maatschappelijke ontwikkelingen hebben op hun beurt ook effect op factoren in de bredere sociale context, het gezin of het individuele domein (Bronfenbrenner, 1977; Coleman, 1990). Om veranderingen in jeugddelinquentie over de tijd te kunnen verklaren is het relevant om ook veranderingen op microniveau te bestuderen. Dergelijk onderzoek ontbreekt nagenoeg omdat gegevens over de tijd veelal niet voorhanden zijn (Roth e.a., 2012). ${ }^{4}$ Dit betreft zowel verklaringen over de tijd voor veranderingen in jeugddelinquentie in het algemeen als in ernstige jeugddelinquentie.

In deze studie proberen we een deel van deze lacune op te vullen. De centrale vraag is: In hoeverre bieden ontwikkelingen die zich van 2005 tot en met 2015 hebben voorgedaan in risico- en beschermende factoren (individueel, binnen het gezin en de vriendengroep en op school) een verklaring voor de daling in zelfgerapporteerde jeugddelinquentie in de periode 2005-2015 in Nederland?

\section{Theorie en eerder onderzoek}

In een toepassing van de biopsychosociale ecologische theorie van Bronfenbrenner (1977; Bronfenbrenner \& Ceci, 1994) als verklaring voor delinquentie, namelijk het cumulatieve ontwikkelingsmodel (Loeber e.a., 2008), staan risico- en beschermende factoren in verschillende leefdomeinen centraal. Factoren in verschillende leefdomeinen, zoals die van het individu, het gezin, de vriendengroep, de school of de buurt, zijn van invloed op iemands gedrag. In de theorie van Bronfenbrenner (1977) wordt het individu gezien als 'genest' binnen de verschillende systemen van gezin, de bredere sociale context als vriendengroep, school of buurt en de brede maatschappelijke context. Individueel gedrag is het resultaat van een 
wisselwerking tussen factoren uit de verschillende leefdomeinen. Volgens het cumulatieve ontwikkelingsmodel wordt de kans op delinquentie vergroot door risicofactoren en verkleind door beschermende factoren in deze domeinen (Loeber e.a., 2008; Pollard e.a., 1999). Risico- en beschermende factoren kunnen een direct effect hebben op delinquentie of een indirect effect. Een indirect effect betreft een bufferende werking van protectieve factoren, waardoor het directe effect van een risicofactor wordt gedempt of teniet wordt gedaan (Loeber e.a., 2008). In dit onderzoek maken we geen onderscheid tussen directe en indirecte effecten.

Er is veel bekend over welke factoren in de adolescentieperiode gerelateerd zijn aan delinquentie (Loeber e.a., 2008; Tanner-Smith e.a., 2013). Risicofactoren in het individuele domein zijn bijvoorbeeld eerder probleemgedrag, alcohol- of drugsgebruik, impulsiviteit en risico's willen nemen (Loeber e.a., 2008). Anderzijds zijn sociaal vaardig gedrag en goed kunnen oriënteren op taken beschermende factoren (Pollard e.a., 1999). In het gezinsdomein versterken negatieve opvoedingsstijlen, zoals negeren, vijandigheid en verwaarlozen van kinderen door ouders, de kans op delinquentie (Loeber e.a., 2008). Anderzijds wordt delinquentie gedempt door emotionele steun en monitoring van ouders (Hoeve e.a., 2009), openheid van kinderen naar ouders toe (Hoeve e.a., 2009; Stattin \& Kerr, 2000) en een goede band met ouders (Hoeve e.a., 2012). In het vriendendomein is delinquentie van vrienden een belangrijke risicofactor voor eigen delinquentie (Loeber e.a., 2008). In het domein van de school zijn slechte schoolprestaties (Maguin \& Loeber, 1996) en slechte binding met school risicofactoren, terwijl binding met leerkrachten bescherming kan bieden (Stouthamer-Loeber e.a., 2002).

Hoe kunnen risico- en beschermende factoren bij adolescenten de daling in jeugddelinquentie in opeenvolgende cohorten over de tijd verklaren? Het cumulatieve ontwikkelingsmodel (Loeber e.a., 2008) biedt een verklaring voor delinquentie op microniveau, zowel wat betreft de prevalentie als wat betreft de ernst van delinquentie. Verwacht kan worden dat als op microniveau veranderingen optreden in risico- en beschermende factoren, dit uiteindelijk ook effecten heeft op macroniveau (Bronfenbrenner, 1977; Coleman, 1990). Vanuit deze gedachte biedt het ontwikkelingsmodel een verklaring voor veranderingen in delinquentie op populatieniveau over de tijd. Er zijn verschillende mechanismen waardoor risico- en beschermende factoren effect kunnen hebben op delinquentie (Bronfenbrenner, 1977; Loeber e.a., 2008).

Ten eerste is gevoeligheid voor risico-/beschermende factoren relevant. Dit betreft de mate waarin een risicofactor (beschermende factor) de kans op delinquentie vergroot (verkleint). Zo blijken eerder probleemgedrag en delinquente vrienden sterker gerelateerd aan delinquentie dan familie- of schoolfactoren (TannerSmith e.a., 2013). Ook verschilt de gevoeligheid voor risicofactoren tussen groepen; er zijn verschillen naar sekse (Wong, 2012) of herkomstgroepen (Wallace \& Muroff, 2002) in de mate waarin ze gevoelig zijn voor risicofactoren. Als zich over de tijd in opeenvolgende cohorten van jongeren veranderingen voordoen in de gevoeligheid voor risico-/beschermende factoren kan dit gevolgen hebben voor delinquentie. Jongeren kunnen bijvoorbeeld minder gevoelig worden voor delinquentie van vrienden, omdat interacties met vrienden veranderen. Eerder onder- 
zoek hiernaar is ons niet bekend, alhoewel studies naar middelengebruik onder jongeren laten zien dat er over de tijd nauwelijks verandering is in de sterkte van de associaties van risicofactoren met middelengebruik, ongeacht de frequentie en de ernst van het middelengebruik (Brown e.a., 2001; De Looze e.a., 2014; Donovan e.a., 1999; Patrick \& Schulenberg, 2017).

Ten tweede kan blootstelling aan deze factoren delinquentie verklaren. Blootstelling betreft de mate waarin iemand te maken krijgt met een risico- of een beschermende factor. Als zich over de tijd veranderingen voordoen in de mate van blootstelling, kan dit consequenties hebben voor delinquentie. Bijvoorbeeld als nieuwe generaties van jongeren minder alcohol drinken, of als ze meer ouderlijke steun of betrokkenheid bij hun vrijetijdsactiviteiten ervaren, dan kan dit delinquentie dempen. Trendstudies laten veranderingen zien in de mate waarin opeenvolgende cohorten van Nederlandse jongeren worden blootgesteld aan enkele eerdergenoemde factoren. In de jaren 2001-2013 is onder middelbare scholieren sprake van een afname in het alcohol- en drugsgebruik ${ }^{5}$ en een toename in het ervaren contact met en zorgtaken door ouders, de schoolwaardering en ervaren schoolprestaties (De Looze e.a., 2014; Keizer \& Dykstra, 2013).

De prevalentie van delinquentie, d.w.z. het wel of niet plegen van delicten, kan worden verklaard door gevoeligheid voor en blootstelling aan risico- of beschermende factoren. Ernstige delinquentie is volgens het cumulatieve ontwikkelingsmodel het resultaat van een cumulatie aan risicofactoren (de 'dose-response'-relatie). De kans op ernstige delinquentie neemt toe bij een opeenstapeling van risicofactoren (Loeber e.a., 2008; Pollard e.a., 1999), terwijl een cumulatie van beschermende factoren de kans op (ernstig) probleemgedrag dempt (Stouthamer-Loeber e.a., 2002). Als in opeenvolgende cohorten blootstelling aan meerdere risicofactoren tegelijk afneemt en/of blootstelling aan meerdere beschermende factoren toeneemt, dan is te verwachten dat ook ernstige delinquentie afneemt.

Op basis van theorie en eerder onderzoek verwachten we dat, ongeacht de ernst van delinquentie, de samenhang van risico- en beschermende factoren met delinquentie (gevoeligheid) stabiel is voor elkaar over de tijd opeenvolgende cohorten van jongeren. Ook verwachten we dat de daling in delinquentie onder jongeren in Nederland gepaard gaat met een afname in de blootstelling aan risicofactoren of een toename in de blootstelling aan beschermende factoren. Verder verwachten we dat een afname in de cumulatie van risicofactoren en/of een toename in de cumulatie van beschermende factoren samenhangen met een afname in ernstige delinquentie. In het vervolg van dit artikel beschrijven we hoe we deze verwachtingen empirisch hebben getoetst.

5 Volgens De Looze e.a. (2014) is het denkbaar dat de daling in alcoholgebruik onder tieners (mede) het resultaat is van nationale preventiestrategieën om het alcoholgebruik onder jongeren terug te dringen, waaronder mediacampagnes en de wettelijke ophoging van de leeftijdsgrens voor de verkoop van alcohol. Zij merken hierbij wel op dat in andere Europese landen ook sprake is van een daling in alcoholgebruik terwijl daar dergelijke nationale initiatieven niet zijn, waardoor de verklaring voor de daling waarschijnlijk eerder ligt in meer algemene culturele veranderingen. 


\section{Methode}

In deze studie zijn gegevens gebruikt van drie metingen van de Monitor Zelfgerapporteerde Jeugdcriminaliteit (MZJ; de 2005-, 2010- en 2015-cohorten), een face-to-facesurvey onder representatieve steekproeven van Nederlandse jongeren. We richten ons op 12- tot 18-jarigen omdat voor deze leeftijdsgroep voor alle metingen gegevens beschikbaar zijn. De steekproeftrekking en survey zijn over de jaren vergelijkbaar (Engelen e.a., 2015; Van der Laan \& Blom, 2006; Verburg, 2011), waardoor sprake is van een repeated cross-sectional design.

Het steekproefkader is de Gemeentelijke Basisadministratie (GBA). Er is een gestratificeerde steekproef getrokken, waarbij de strata zijn ingedeeld naar leeftijd en herkomst. Binnen de strata zijn de (adressen van) jongeren random geselecteerd. Alle legaal in Nederland wonende jongeren kunnen in de steekproeven komen, met uitzondering van jongeren die wonen in het Caribisch gebied of op de Waddeneilanden. Illegalen en toeristen blijven buiten beschouwing.

De gecorrigeerde respons onder de $12-18$-jarigen is 67,0 procent (2005), 65,7 procent (2010) en 61,8 procent (2015) en is in alle jaren acceptabel (aldus Stoop, 2005), maar wel afnemend. In alle cohorten is een ondervertegenwoordiging van jongens van Marokkaanse en Turkse herkomst (responspercentages rond de 50 procent). De ondervertegenwoordiging is klein, waardoor de steekproef nauwelijks selectief is (Engelen e.a., 2015). Er zijn geen aanwijzingen dat de non-respons over de tijd selectiever is geworden wat betreft politiecontacten. Politieregistraties laten zien dat het percentage jeugdigen dat als verdachte is geregistreerd in de non-respons is gedaald van 21,2 procent in 2010 (Weijters e.a., 2016) naar 10,4 procent in 2015 (Engelen e.a., 2015). De gegevens zijn per meting achteraf gewogen op de kenmerken sekse, leeftijd, herkomst, opleidingsniveau, stedelijkheidsgraad en landsdeel, waardoor de onderzoeksgroepen representatief zijn voor 12-18-jarigen in Nederland.

Voor de onderzoeksperiode 2005-2015 zijn gegevens beschikbaar van 4.585 jongeren (de gewogen $\mathrm{N}=4.856$ (2005-cohort=23,1 procent; 2010 -cohort $=46,6$ procent; 2015-cohort=30,3 procent); 50,9 procent jongens; 76,8 procent van autochtone herkomst; leeftijd $\mathrm{M}=14,5$ ( $\mathrm{SD}=1,7) ; 84,2$ procent is afkomstig uit een tweeoudergezin). Op de demografische variabelen verschillen de groepen niet significant van elkaar, alleen het aandeel tweeoudergezinnen is in 2015 met 90,4 procent relatief hoger dan in 2005/2010 (81 procent/82 procent; $\chi^{2}(2)=61,8$; $\mathrm{p}<0,01)$.

De volgende variabelen zijn in alle drie de metingen gemeten (tabel 1).

Zelfgerapporteerde delinquentie in de afgelopen twaalf maanden is gemeten met 27 items betreffende gewelds- en vermogensdelicten, vernieling en openbare-ordeen drugsdelicten (zie bijlage 1 voor de items). De items betreffen wettelijk strafbaar gedrag en variëren in zwaarte van het feit. Bij de zelfrapportagevragen wordt overwegend gevraagd naar lichte en veelvoorkomende feiten, zoals vandalisme of winkeldiefstal van minder dan 5 euro, maar ook naar zwaardere feiten, zoals inbraak of beroving. Uit een koppeling van de zelfrapportage aan politiegegevens blijkt dat zelfrapportage vooral de lichtere feiten betreft (Weijters e.a., 2016). Per item is gevraagd of de jongere dit ooit, en zo ja hoe vaak in de afgelopen twaalf 
maanden, heeft gepleegd. De afhankelijke variabelen zijn de twaalfmaandsprevalentie en de ernst van delinquentie. De prevalentie is het percentage jongeren dat ten minste een van de 27 delicten eenmaal rapporteert. Ernst van delinquentie betreft een combinatie van frequentie en zwaarte van het feit (Piquero e.a., 2003). Op basis van een delinquentieschaal zijn ernstig delinquente jongeren onderscheiden van niet- en licht delinquente jongeren. Aan de jongeren is gevraagd hoe vaak ze een delict in het afgelopen jaar hebben gepleegd. Op basis van strafdreiging zijn de delicten vervolgens ingedeeld in lichte (bijvoorbeeld vandalisme; score 1) of zware feiten (een wettelijke strafdreiging van minimaal 48 maanden, bijvoorbeeld inbraak; score 2). Ook zijn de delicten ingedeeld naar frequentie. Lichte delicten zijn gecodeerd met 0 ( 0 keer gepleegd in de afgelopen 12 maanden), 1 (1-4 keer) of 2 (5 keer of vaker), zware delicten met 0 (0 keer), 1 (1 keer), 2 (2-4 keer), 3 (5-10 keer) of 4 (11 keer of vaker). Voor elk delict zijn zwaarte en frequentie met elkaar vermenigvuldigd. De delinquentieschaal is een som van multiplicatieve scores (d.w.z. frequentie ${ }^{*}$ zwaarte feit), waarbij een hogere score ernstiger delinquent gedrag betreft. Jongeren die geen delicten hebben gepleegd, rekenen we tot de groep niet-delinquenten en de bovenste 10 procent van de empirische verdeling betreft de groep ernstig delinquenten (Van der Laan \& Blom, 2006).

De onafhankelijke variabelen zijn dertien factoren verspreid over drie leefdomeinen. Vijf factoren betreffen het individuele domein. Psychosociale problematiek is gemeten met de Strengths and Difficulties Questionnaire (SDQ; Goodman, 1997; Van Widenfelt e.a., 2003). De schaal bestaat uit negentien items ${ }^{6}$ en meet hyperactiviteit, aandachts-, emotionele en gedragsproblemen en problemen met leeftijdgenoten. De schaal is de gemiddelde score op de items, waarbij een hogere score wijst op meer psychosociale problematiek. Daarnaast is prosociaal gedrag gemeten met vijf items afkomstig uit de SDQ. Ook hier is het gemiddelde van de scores op de items berekend. Een hogere score betekent meer prosociaal gedrag. Alle SDQ-items zijn gescoord op een 3-punts Likertschaal. Alcohol- en drugsgebruik zijn gemeten met vragen uit het Peilstationonderzoek (Monshouwer e.a., 2004). Alcoholgebruik door de week is gemeten door te vragen naar het aantal dagen dat een jongere doordeweeks alcohol drinkt, waarbij vrijdag als een weekenddag telt. Alcoholgebruik in het weekend is gemeten door te vragen naar het aantal dagen dat een jongere in het weekend alcohol drinkt. Een hogere score op deze schalen betekent meerdere dagen alcoholgebruik. Drugsgebruik is gemeten door te vragen of een jongere ooit drugs heeft gebruikt (softdrugs, harddrugs en partydrugs). De uiteindelijke variabele drugsgebruik is gedichotomiseerd (niet/wel gebruikt).

6 Uit de oorspronkelijke schaal is één item verwijderd, nl. 'dingen wegnemen die niet van mezelf zijn', omdat in de afhankelijke variabele delinquentie ook het item 'diefstal' zit. 
Binnen het gezinsdomein zijn de door de jongere gepercipieerde relatie met en de opvoedingsstijl van de ouders gemeten met vijf schalen. ${ }^{7}$ Emotionele steun meet de gepercipieerde relatie met ouders en is gebaseerd op de EMBU-C (Markus e.a., 2003; Veenstra e.a., 2006). De volgende drie opvoedingsstijlschalen zijn afkomstig van Stattin en Kerr (2000; Pietersma \& Veenstra, 2004). Openheid naar ouders meet de mate waarin een jongere zijn of haar ouders spontaan op de hoogte brengt van vrijetijdsactiviteiten. Informeren door ouders meet de mate waarin ouders zelf informeren naar de vrijetijdsactiviteiten van hun kinderen. Controle door ouders meet de mate waarin ouders de activiteiten van hun kind reguleren. Monitoring door ouders meet de kennis die ouders volgens de jongere zelf hebben over het gedrag van hun kind. Deze laatste schaal is afkomstig van Fletcher e.a. (2004). De schaal monitoring door ouders is gemeten op een 3-punts Likertschaal, de overige op een 5-punts Likertschaal. Hogere scores op deze schalen betekenen respectievelijk dat jongeren meer emotionele steun ervaren, opener zijn naar hun ouders over hun activiteiten en dat ouders meer informeren naar hun (vrijetijds)activiteiten en deze controleren.

De bredere sociale context betreft vrienden en school. Delinquentie vrienden meet met vijf items op een 4-punts Likertschaal in hoeverre een jongere vrienden heeft die wel eens offline delicten hebben gepleegd. Een hogere score betekent dat een jongere delinquentere vrienden heeft. Twee schalen hebben betrekking op school. Beide schalen zijn afkomstig van het NSCR-schoolproject (Weerman e.a., 2003). Schoolprestaties meet met één item de gemiddelde schoolprestaties van een jongere in het afgelopen jaar. Een hogere score betekent betere schoolprestaties. Tevredenheid met school meet met vijf items de mate waarin een jongere tevreden is met school (5-punts Likertschaal). Een hogere score betekent een hogere mate van tevredenheid met school.

7 In 2015 hebben de vragen over opvoedstijlen betrekking op 'ouders'; in de jaren 2005 en 2010 zijn de items voor vader en moeder afzonderlijk gesteld. De correlaties tussen de schalen voor vader en moeder waren in 2005 en 2010 r>0,64. Factoranalyses lieten vergelijkbare factorstructuren zien voor vader en moeder. Voor deze jaren zijn de schalen voor vader en moeder samengenomen door het gemiddelde te bepalen op de afzonderlijke schalen. 


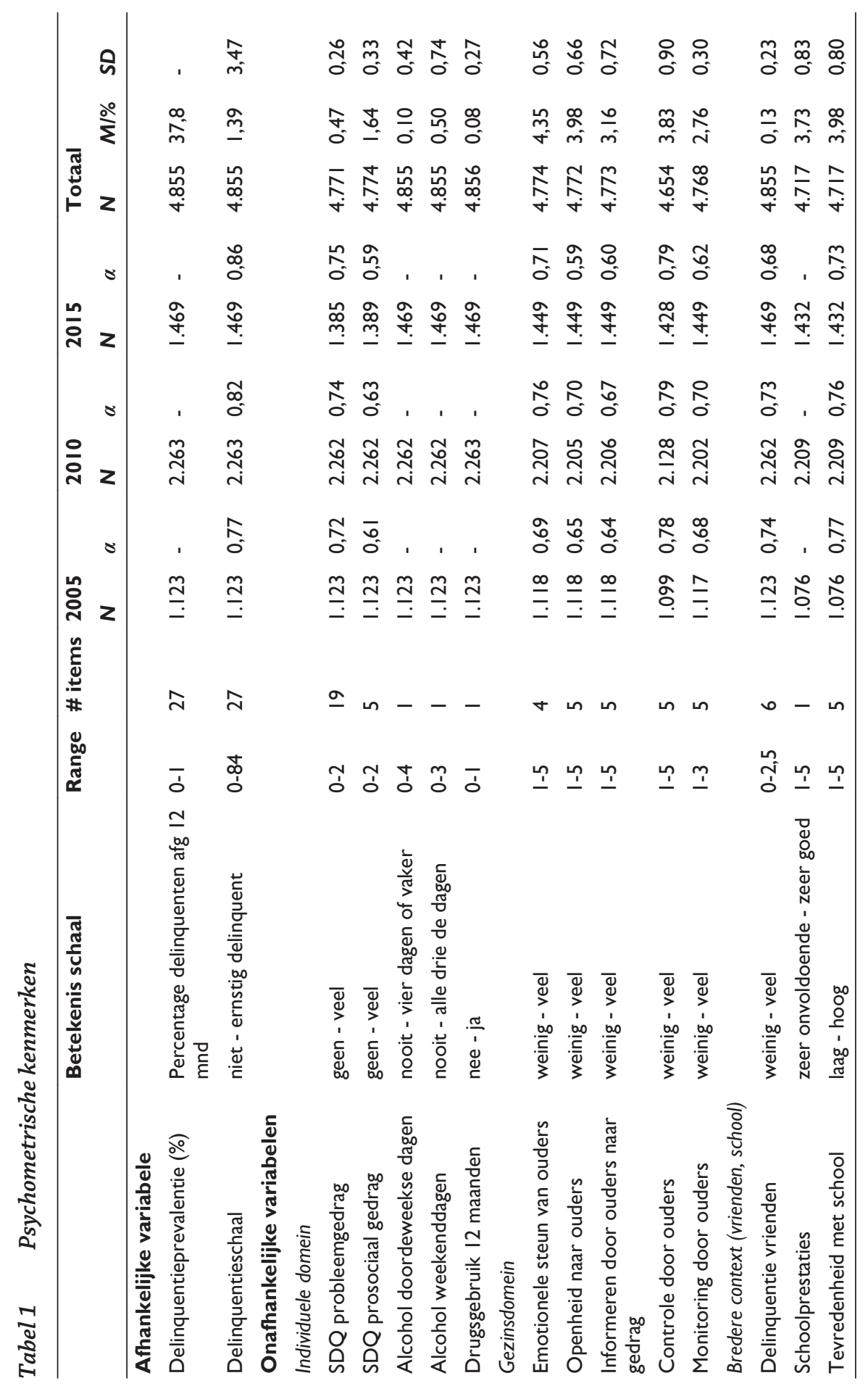




\section{Analyses}

Om de gevoeligheid voor specifieke factoren te meten zijn logistische regressieanalyses uitgevoerd. Per cohort is voor elke factor afzonderlijk de samenhang met delinquentie bepaald en gelijktijdig is met interactietermen vastgesteld of de sterkte van de samenhang verschilde met die in de andere cohorten en is gecorrigeerd voor demografische kenmerken (sekse, leeftijd, herkomst en gezinssamenstelling).

De mate waarin jongeren zijn blootgesteld aan factoren gerelateerd aan delinquentie is bepaald door per cohort de gemiddelde scores op de factoren te berekenen. Met ANOVA's is nagegaan op welke factoren er overall significante verschillen waren. In post-hoc analyses met Bonferroni-correctie is nagegaan welke cohorten significant van elkaar verschilden.

Vervolgens is onderzocht in hoeverre de gemiddelde scores op de cumulatie van risico- en beschermende factoren tussen de cohorten verschilden. Cumulatieve risico- en beschermende somscores zijn berekend volgens de Burgess-methode (Farrington \& Loeber, 2000). De gedachte is dat risico- en beschermende factoren de tegenovergestelde uiteindes zijn van eenzelfde dimensie. Per factor is een dummyvariabele gemaakt met een lage (beneden 25ste percentiel) en een hoge score (boven 75ste percentiel). Afhankelijk van de variabele betrof het een beschermende of risicocomponent. Zo zijn bij probleemgedrag, alcohol- en drugsgebruik en delinquentie vrienden hoge scores een risicocomponent en lage scores een beschermende component (indien aanwezig). Bij variabelen betreffende de opvoedstijlen van ouders, prosociaal gedrag, schoolprestaties en tevredenheid met school zijn lage scores een risicocomponent en hoge scores een beschermende component. Per domein zijn de risicocomponenten (beschermende componenten) bij elkaar opgeteld tot een cumulatieve risicoscore (beschermende score). Omdat de cumulatieve scores zijn bepaald over een relatieve maat (de percentielscores) zijn de gegevens van de drie cohorten samengenomen, zodat verschuivingen over de tijd kunnen worden berekend.

Om kanskapitalisatie te vermijden is in alle analyses een significantieniveau van $\mathrm{p}<0,01$ gebruikt.

\section{Resultaten}

Uit tabel 2 blijkt dat de prevalentie van delinquentie in de opeenvolgende metingen is gedaald, alleen is de prevalentie in het 2015-cohort significant lager dan in het 2005-cohort. Het percentage niet-delinquenten is significant toegenomen (+11 procent), terwijl het percentage ernstig delinquenten significant is afgenomen (-37 procent). Het percentage licht delinquenten is gedaald ( -9 procent), maar niet significant. De gemiddelde score op de delinquentieschaal is in het 2015-cohort significant lager dan in het 2005-cohort.

De daling van ernstig delinquenten in het 2015-cohort ten opzichte van eerdere cohorten betreft alleen een daling in prevalentie. De frequentie en ernst van delinquentie bij deze groep verschillen in 2015 niet significant van eerdere cohor- 
Tabel 2 Beschrijvende statistieken: delinquentie; totaal, naar type en delinquentieschaal (gewogen)

\begin{tabular}{|c|c|c|c|c|}
\hline Variabelen & $\begin{array}{l}2005 \\
(\mathrm{~N}=I . I 23)\end{array}$ & $\begin{array}{l}2010 \\
(\mathrm{~N}=2.263)\end{array}$ & $\begin{array}{l}2015 \\
(N=1.469)\end{array}$ & $\begin{array}{l}\text { Totaal } \\
(\mathrm{N}=4.855)\end{array}$ \\
\hline \multicolumn{5}{|l|}{$\begin{array}{l}\text { Delinquentiepreva- } \\
\text { lentie }(\%)^{l}\end{array}$} \\
\hline Totaal & $41,2^{c}$ & 38,1 & $34,7^{a}$ & 37,8 \\
\hline \multicolumn{5}{|l|}{ Naar groep' } \\
\hline $\begin{array}{l}\text { Niet delinquent } \\
(P<25)\end{array}$ & $58,8^{c}$ & 61,9 & $65,3^{\mathrm{a}}$ & 62,2 \\
\hline Licht delinquent & 30,4 & 28,9 & 27,7 & 28,9 \\
\hline $\begin{array}{l}\text { Ernstig delinquent } \\
(P>90)\end{array}$ & $10,9^{c}$ & 9,1 & $6,9^{\mathrm{a}}$ & 8,9 \\
\hline \multicolumn{5}{|l|}{$\begin{array}{l}\text { Delinquentieschaal } \\
(M ;(S D))^{2}\end{array}$} \\
\hline Totale groep & $\mathrm{I}, 58(3,34)^{\mathrm{c}}$ & $\mathrm{I}, 44(3,62)^{\mathrm{c}}$ & $\mathrm{I}, \mathrm{I} 8(3,30)^{\mathrm{ab}}$ & I,39 $(3,47)$ \\
\hline $\begin{array}{l}\text { Ernstig delinquen- } \\
\text { ten }\end{array}$ & $9,14(5,40)$ & $10,23(7,02)$ & $10,08(7,06)$ & $9,89(6,80)$ \\
\hline \multicolumn{5}{|l|}{ Waarvan: } \\
\hline Frequentie & $19,65(11,37)$ & $20,19(14,31)$ & $20,83(13,73)$ & $20,19(13,38)$ \\
\hline Ernst feit & $6,4 \mid(2,90)$ & $7,44(3,78)$ & $6,63(3,47)$ & $6,95(3,50)$ \\
\hline
\end{tabular}

${ }^{2} \chi^{2}$-toets, $\mathrm{p}<0,01$; verschillen tussen jaren o.b.v. adjusted residuals.

2 ANOVA F-toets, $p<0,0$ I; verschillen tussen cohorten o.b.v. post-hoc toetsen met Bonferonnicorrectie.

Significante verschillen tussen de groepen (in de kolommen) worden weergegeven met de letters a, b, c.

ten. Oftewel, er zijn in het 2015-cohort minder ernstig delinquente 12-18-jarigen dan in eerdere cohorten, maar deze groep zegt nog steeds in dezelfde frequentie en zwaarte van feiten delicten te plegen.

Een eerste mogelijke verklaring voor de daling in delinquentie is verandering in gevoeligheid voor risico- of beschermende factoren over de tijd. Uit tabel 3 blijkt dat twaalf van de dertien factoren in alle jaren significant $(\mathrm{p}<0,01)$ samenhangen met de prevalentie van delinquentie, behalve alcoholgebruik door de week (in 2005 p-waarde=0,05; in 2015 p-waarde=0,02). Om na te gaan of de factoren tussen de cohorten verschillen in sterkte van de samenhang zijn in de logistische regressies per cohort interactie-effecten berekend met andere cohorten. De 42 mogelijke (niet-getoonde) interactie-effecten laten geen significante verschillen zien.

Bij de ernstig delinquenten hangen tien van de dertien factoren in alle cohorten significant $(\mathrm{p}<0,01)$ samen met delinquentie, behalve informeren door ouders (in 2010 p-waarde=0,014; in 2015 p-waarde=0,06), controle door ouders (in 2005 pwaarde=0,03; in 2015 p-waarde=0,01) en schoolprestaties (in 2015 p- 
waarde=0,04). Van de 42 interactie-effecten bleken drie significant: prosociaal gedrag hangt in het 2015-cohort minder sterk samen met delinquentie dan in het 2010-cohort (interactie $2010 \mathrm{~b}=-1,07$; s.e. $=0,36$; $\mathrm{p}<0,01$ ); de delinquentie van vrienden hangt in 2015 en 2010 sterker samen met eigen delinquentie dan in het 2005-cohort (interactie $2010 \mathrm{~b}=1,40$; s.e. $=0,48$; $\mathrm{p}<0,01$; interactie $2015 \mathrm{~b}=1,89$; s.e. $=0,57 ; \mathrm{p}<0,01)$.

De resultaten wijzen erop dat de daling in prevalentie van delinquentie hoogstwaarschijnlijk niet toe te schrijven is aan veranderingen in gevoeligheid voor risico- en beschermende factoren; alleen onder ernstig delinquenten zien we dat in de recentste cohorten delinquentie van vrienden een sterkere impact heeft op eigen delinquentie dan in het 2005-cohort.

Een tweede mogelijke verklaring voor de daling in delinquentie is dat over de tijd de blootstelling aan risicofactoren is afgenomen, of aan beschermende factoren is toegenomen. In tabel 4 worden de gemiddelden per cohort gegeven. De gemiddelden verschillen significant van elkaar $(\mathrm{p}<0,01)$, behalve voor schoolprestaties (Ftoets $(2,4.13)=3,49 ; \mathrm{p}=0,03)$ en drugsgebruik (F-toets $(2,4.852)=0,72 ; \mathrm{p}=0,49)$. Negen van de dertien factoren laten trends in de verwachte richting zien: een daling in blootstelling aan risico's en een toename in blootstelling aan bescherming. Binnen het individuele domein blijkt in het 2015-cohort ten opzichte van eerdere cohorten een significante toename in de gemiddelde score op prosociaal gedrag en een significante afname in het gemiddeld aantal dagen dat jongeren doordeweeks en in het weekend alcohol drinken. De significante toenames in gemiddelde scores op alle opvoedingsvariabelen in de opeenvolgende cohorten wijzen erop dat jongeren over de jaren heen een hogere mate van bescherming ervaren in de opvoedstijl van hun ouders. Binnen de bredere context vinden we een significante daling in de gemiddelde score op delinquente vrienden. Tegengesteld aan de verwachtingen zijn de significante toename in probleemgedrag en afname in tevredenheid met school in 2015 ten opzichte van 2010. De eerste wijst op een toename in de blootstelling aan een risicofactor en de tweede op een afname in de blootstelling aan een beschermende factor.

Onder ernstig delinquenten blijken in het 2015-cohort op vier van dertien factoren significante verschillen met eerdere cohorten. De gemiddelden op prosociaal gedrag, emotionele steun van, openheid naar en informeren door ouders en schoolprestaties laten in 2015 een significante toename zien ten opzichte van eerdere metingen. Op de andere factoren verschillen de gemiddelden van de cohorten niet significant. 


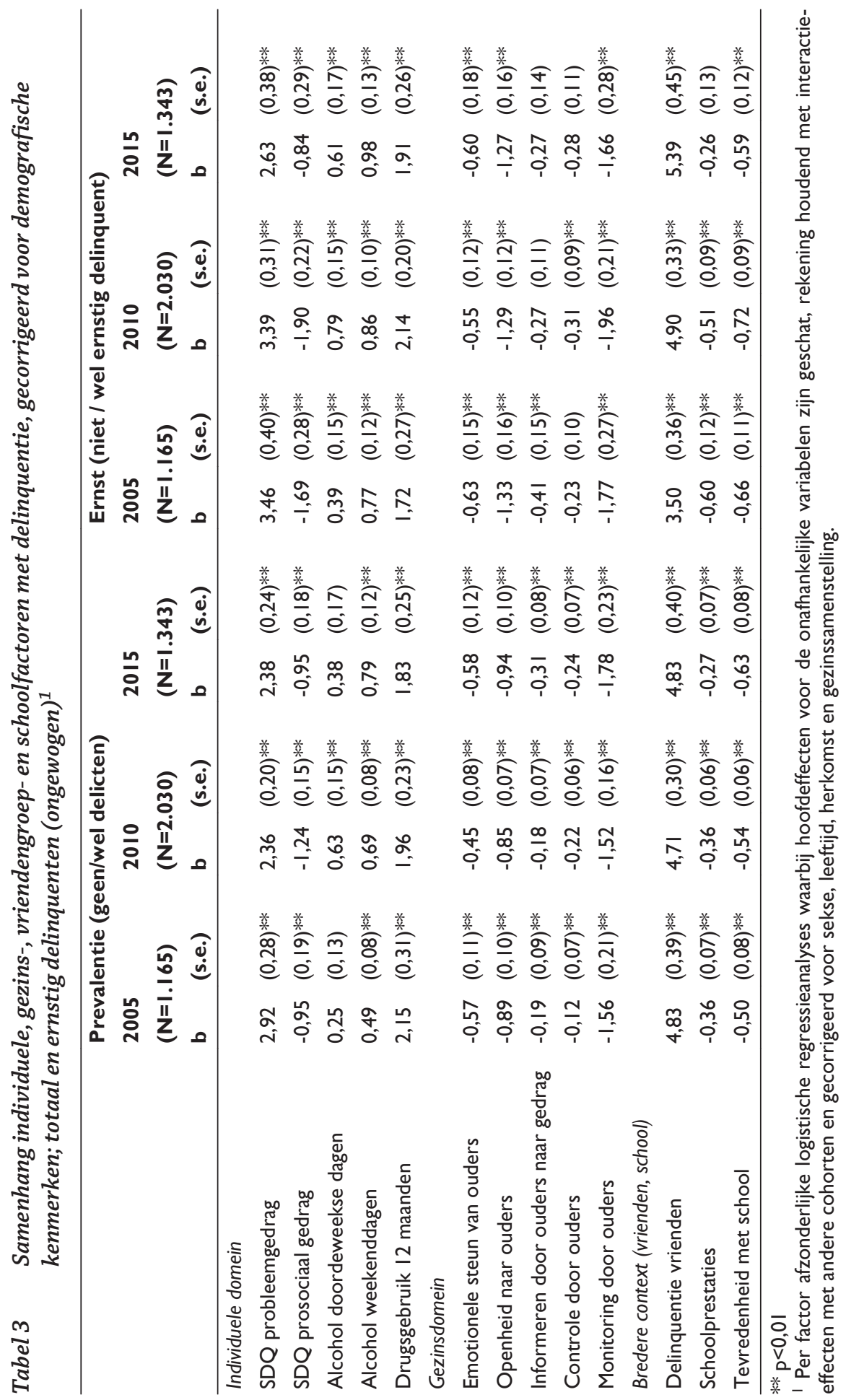




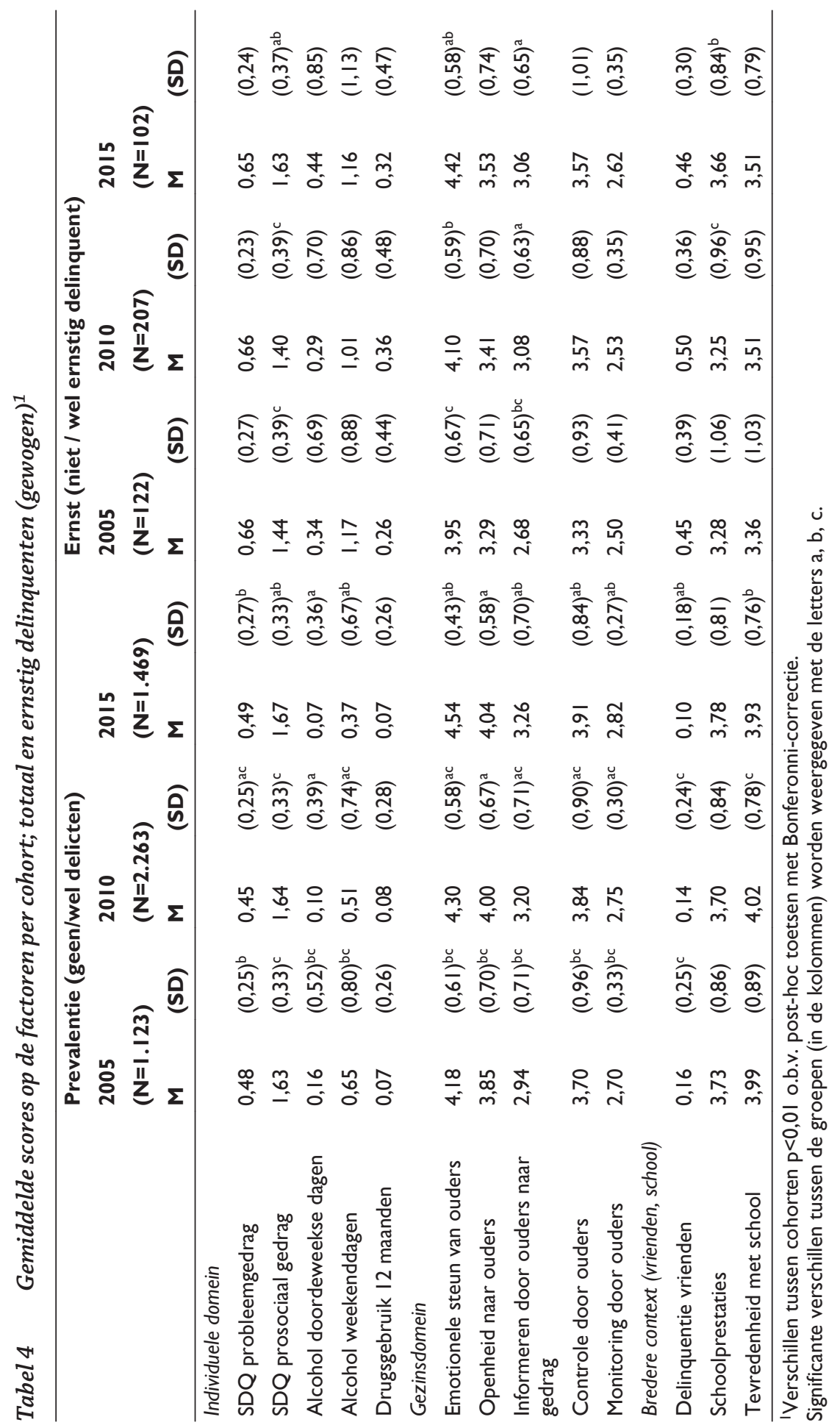


Tot slot is onderzocht of de cohorten verschillen in de cumulatie van risico- of beschermende componenten (figuur 1a). In het 2015-cohort zijn ten opzichte van de eerdere cohorten in alle leefdomeinen de gemiddelden op de cumulatieve risicoscores significant afgenomen. Overall is het gemiddelde op de totale risicoscore - een optelsom van de risicocomponenten uit alle domeinen - significant gedaald. Het gemiddelde op de cumulatieve beschermende scores is binnen het gezinsdomein toegenomen en ook overall is het gemiddelde op de totale beschermende score in 2015 significant toegenomen ten opzichte van eerdere cohorten.

Onder ernstig delinquenten blijkt in het 2015-cohort ten opzichte van eerdere cohorten een significante afname in het gemiddelde op de cumulatieve risicoscore van het gezin (figuur 1b). De cumulatieve risicoscores in het individuele en vrienden/school-domein en de totale risicoscore verschillen in het 2015-cohort niet significant van die in eerdere cohorten. Voor de totaalscore is de trend dalend, maar niet-significant op 1-procentniveau, wat mogelijk het gevolg is van een powerprobleem door de kleine aantallen. Wel zijn er in het 2015-cohort ten opzichte van eerdere cohorten significant hogere gemiddelden op de cumulatieve beschermende scores binnen de domeinen individu, gezin en totaal.

\section{Discussie}

In Nederland daalt de geregistreerde jeugdcriminaliteit na 2007 jaarlijks. Ook de door jongeren zelfgerapporteerde delinquentie daalt in de periode 2005-2015. In drie in de tijd opeenvolgende cohorten van Nederlandse jongeren in de MZJ (2005, 2010, 2015) neemt de prevalentie van delinquentie onder 12- tot 18-jarigen af van 41,2 procent naar 34,7 procent. Er is in de opeenvolgende cohorten een toename in het percentage niet-delinquente jongeren en een afname in het percentage ernstig delinquente jongeren; het percentage licht delinquente jongeren neemt over de jaren heen af, maar deze daling is niet significant. Het percentage ernstig delinquenten is met 37 procent het sterkst afgenomen, waarbij het een daling in prevalentie en niet in frequentie van plegen of zwaarte van feiten betreft. Dat het aandeel ernstig delinquenten onder 12-18-jarigen het sterkst is afgenomen, bevestigt een eerdere gedachte dat het aandeel jongeren dat zware delicten pleegt sterker daalt dan jongeren die lichtere delicten melden (Van der Laan \& Goudriaan, 2016).

In dit onderzoek hebben we de daling van de jeugddelinquentie over de tijd proberen te verklaren vanuit het cumulatieve ontwikkelingsmodel voor delinquentie (Loeber e.a., 2008), wat een toepassing is van de biopsychosociale ecologische theorie van Bronfenbrenner (1977; Bronfenbrenner \& Ceci, 1994). Hiermee kunnen veranderingen in jeugddelinquentie over de tijd worden verklaard door veranderingen in gevoeligheid, blootstelling of cumulatie van risico- en beschermende factoren in verschillende leefdomeinen. Daarbij vinden we verschillen tussen delinquentie in het algemeen (prevalentie) en ernstige delinquentie.

In overeenstemming met onze verwachtingen blijkt de samenhang van de meeste factoren met prevalentie van delinquentie (gevoeligheid) in het algemeen stabiel 


\section{a. Totale groep}

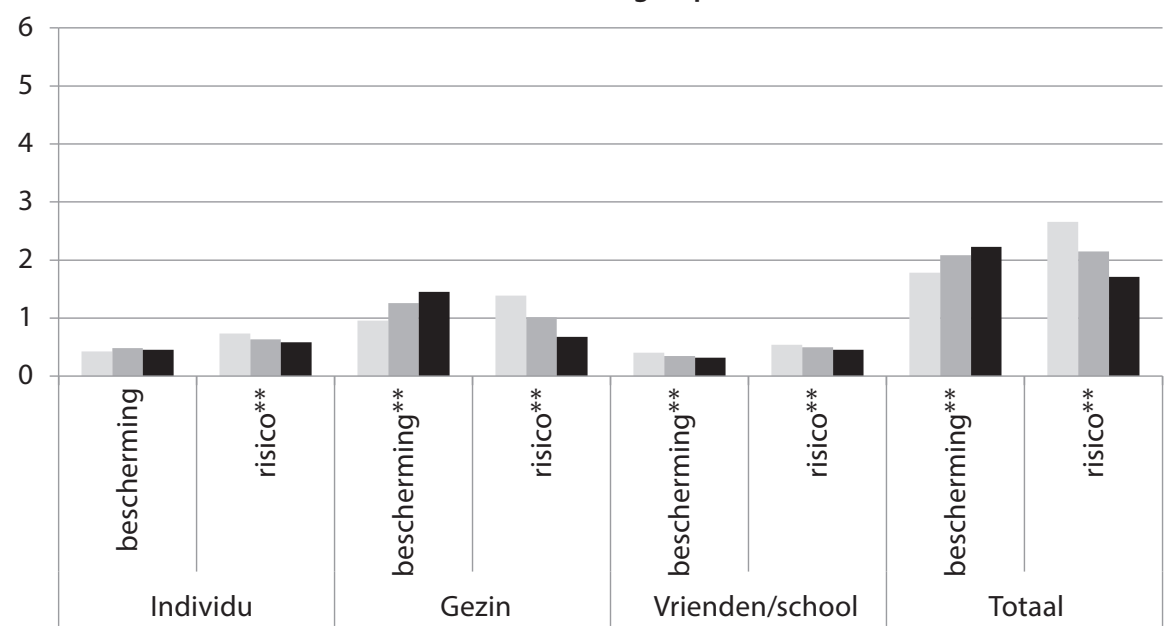

$2005(\mathrm{~N}=1.123) \quad 2010(\mathrm{~N}=2.263) \quad \square 2015(\mathrm{~N}=1.469)$

\section{b. Ernstige delinquentie}

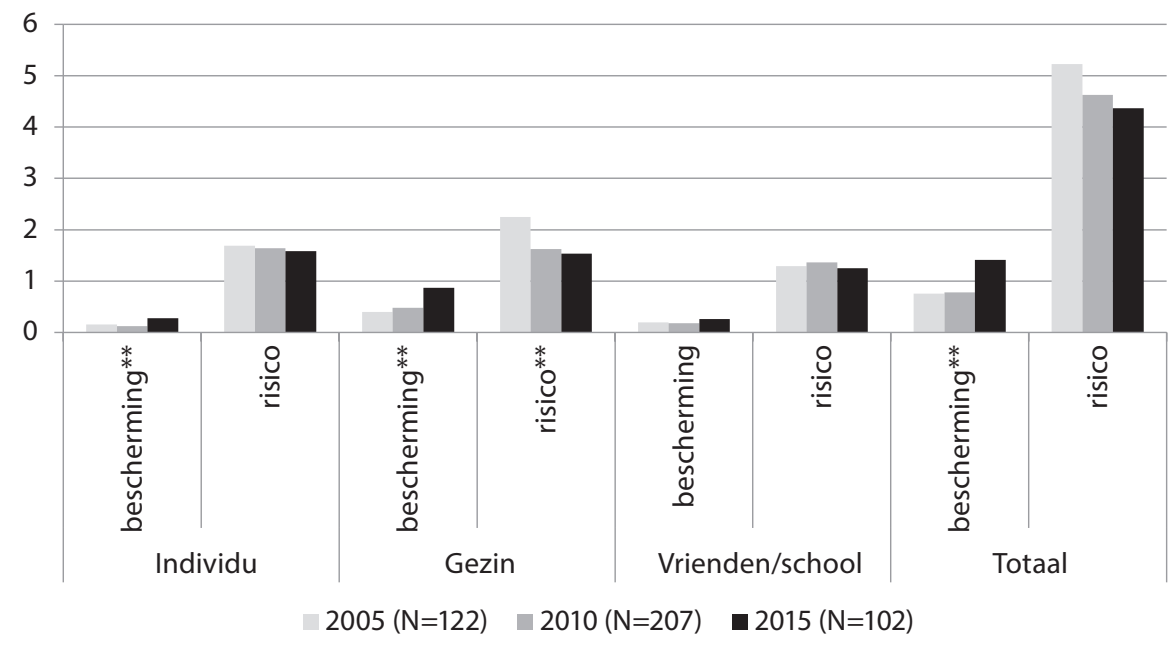

** $p<0,01$ voor 2015-cohort t.o.v. eerdere cohorten.

Figuur 1 Cumulatieve risico-en beschermende scores voor de leefgebieden en totaal

over de tijd. Factoren die in het 2015-cohort positief gerelateerd bleken aan delinquentie (probleemgedrag, alcoholgebruik en delinquentie van vrienden), of negatief ermee samenhingen (prosociaal gedrag, de door de jongere gepercipieerde opvoedingsstijl van ouders, schoolprestaties of tevredenheid met school), hingen in de 2010- en 2005-cohort vergelijkbaar samen met delinquentie. Deze bevindingen sluiten aan bij onderzoek naar middelengebruik, waarvan de predictoren over 
de tijd ook stabiel blijken (Donovan e.a., 1999; Brown e.a., 2001; De Looze e.a., 2014; Patrick \& Schulenberg, 2017). De consistentie van risico- en beschermende factoren over de tijd betekent dat de sociaalpsychologische verklaringen voor het wel of niet plegen van delinquentie voor elkaar in de tijd opeenvolgende cohorten van jongeren intact blijven.

De consistentie van de samenhang van risico- en beschermende factoren met delinquentie over de tijd biedt waarschijnlijk dus geen verklaring voor de daling in de prevalentie van delinquentie. De resultaten tonen wel verandering in blootstelling aan afzonderlijke factoren en cumulatie van risico- en beschermende factoren in verschillende leefdomeinen. Onder 12-18-jarigen meldde het 2015-cohort gunstigere scores op de afzonderlijke factoren dan eerdere cohorten. De blootstelling aan risicogedragingen (middelengebruik) en aan delinquente vrienden was lager dan in eerdere jaren, de blootstelling aan gunstige opvoedingsstijlen hoger. Ook uit ander onderzoek blijkt dat Nederlandse jongeren over de tijd minder middelen zijn gaan gebruiken (De Looze e.a., 2014) en in de opvoeding meer betrokkenheid ervaren van hun ouders (De Looze e.a., 2014; Keizer \& Dykstra, 2013). De daling in de prevalentie van jeugddelinquentie onder 12-18-jarigen kan mogelijk verklaard worden doordat jongeren gemiddeld minder risico- en meer beschermende factoren ervaren. Ook voor de daling in alcoholgebruik onder jongeren wordt als mogelijke verklaring genoemd dat ouders sinds het begin van de 21ste eeuw strikter zijn geworden en op die manier hun kinderen willen beschermen tegen dergelijk risicogedrag (De Looze e.a., 2014). Dit kan wijzen op een veranderende sociaal-culturele houding ten aanzien van risicogedrag, zowel bij jongeren zelf als bij hun ouders (vergelijk Eisner (2014) wat betreft de algemene 'crime drop').

Verder neemt het percentage jongeren dat ernstige delinquentie rapporteert af, maar niet de frequentie waarmee ze delicten plegen en de zwaarte van de feiten. Anders gezegd, er zijn minder jongeren die tot de groep ernstig delinquenten gerekend kunnen worden, maar degenen die overblijven plegen nog wel even vaak delicten en de delicten die ze plegen, zijn nog even zwaar als in eerdere cohorten. Onder deze groep zijn de meeste factoren die samenhangen met delinquentie consistent over de tijd; wel wordt delinquentie van vrienden belangrijker. Daarnaast blijken beperkt veranderingen over de tijd in de blootstelling aan afzonderlijke factoren. Enerzijds melden ernstig delinquenten in het 2015-cohort gemiddeld meer blootstelling aan beschermende factoren op het individuele en gezinsdomein dan in 2005 en minder risico's binnen het gezin. Anderzijds lijkt de blootstelling aan risicogedrag (middelengebruik) en delinquentie van vrienden onder deze jongeren over de tijd stabiel. De daling in de prevalentie van ernstige delinquentie zou kunnen worden verklaard doordat jongeren in het algemeen minder risico's en meer bescherming ervaren, waardoor ze worden weerhouden de stap te zetten naar ernstige delinquentie. Deze consistentie in blootstelling aan individueel risicogedrag en delinquentie van vrienden, gecombineerd met een toegenomen impact van delinquentie van vrienden op eigen delinquentie, kan duidelijk maken waarom de frequentie van plegen en/of zwaarte van de gepleegde feiten onder de groep ernstig delinquente jongeren over de tijd stabiel zijn gebleven. De bevindingen zijn consistent met internationaal onderzoek, waaruit blijkt dat er weliswaar sprake is van een daling in jeugddelinquentie (Eurostat, 2016), maar 
dat over opeenvolgende cohorten in de tijd degenen die met politie in aanraking komen in dezelfde mate blijven recidiveren (Andersen e.a., 2016). ${ }^{8}$ Het is denkbaar dat er in elk nieuw cohort een weliswaar slinkende, maar 'harde' kern van jongeren overblijft. Bij deze jongeren is niet alleen de gevoeligheid voor risicofactoren stabiel over de tijd, maar ook de blootstelling eraan is vergelijkbaar met ernstig delinquente jongeren uit eerdere cohorten (zoals persoonlijkheidsfactoren; zie Caspi e.a., 1994), waardoor ze even vaak of even zware delicten plegen als voorgaande cohorten van ernstig delinquenten. Nader onderzoek is nodig naar welke unieke factoren opeenvolgende cohorten van ernstig delinquente jongeren kenmerken.

Het onderzoek kent enkele beperkingen. Ten eerste is de gewogen respons over de tijd licht gedaald, hoewel deze ook in 2015 nog steeds acceptabel is (aldus Stoop, 2005). De selectiviteit van de onderzoeksgroep betreft in alle metingen een ondervertegenwoordiging van Turkse en Marokkaanse jongens. We verwachten echter dat dit weinig consequenties heeft voor vergelijkbaarheid over de tijd, omdat de selectiviteit van de cohorten nauwelijks verschilt (Engelen e.a., 2015). We vonden ook geen aanwijzingen voor een toenemende non-respons onder jongeren die met de politie in aanraking zijn gekomen. De hoge respons over de verschillende metingen geeft aanleiding te stellen dat de resultaten gelden voor de Nederlandse jongeren in de onderzochte jaren. Ten tweede zijn in 2015 enkele wijzigingen doorgevoerd door voor ouders gezamenlijk te vragen naar opvoedingsstijlen (i.p.v. afzonderlijk). Dit kan mogelijk hebben geleid tot een trendbreuk in deze variabelen. We verwachten echter dat dit effect niet groot is, aangezien de dalende trends in gemiddelde scores op deze variabelen ook in $2010 \mathrm{al}$ zichtbaar waren. Daarbij komt dat ook op andere variabelen die wel vergelijkbaar zijn gemeten over de tijd ook dalingen zichtbaar zijn. Ten derde zijn onze gegevens gebaseerd op zelfrapportage. Daarbij speelt het probleem van over- en onderrapportage voor delinquentie. Eerder onderzoek laat zien dat zelfrapportage van delinquentie valide en betrouwbaar is (Jolliffe \& Farrington, 2014), maar vooral degenen betreft die minder en minder zware feiten plegen (Weijters e.a., 2016). Daarom hebben de bevindingen niet zonder meer betrekking op alle delinquente jongeren. Een opmerking hierbij is dat de zelfgerapporteerde delicten die in deze studie zijn meegenomen betrekking hebben op de traditionele delicten die offline worden gepleegd en niet op cyber- of gedigitaliseerde delicten. Een vierde beperking zijn de crosssectionele data, waardoor causale uitspraken niet mogelijk zijn. Om effecten van bijvoorbeeld gezinskenmerken op delinquentie over de tijd vast te stellen is prospectief longitudinaal onderzoek nodig.

Wat betekenen de bevindingen voor theorie en praktijk? Volgens het cumulatieve ontwikkelingsmodel is individuele delinquentie te verklaren door gevoeligheid voor of blootstelling aan risico- en/of beschermende factoren in verschillende leefdomeinen. Uit dit onderzoek blijkt dat het model ook kan worden toegepast als verklaring voor ontwikkelingen in delinquentie over de tijd. De afname in (zelfgerapporteerde) jeugddelinquentie, zowel algemene als ernstige delinquentie,

8 Ook in Nederland blijkt een vergelijkbare trend wat betreft de recidive onder minderjarigen die met justitie in aanraking zijn geweest (zie hiervoor https://wodc-repris.nl/Repris.html). 
wordt niet verklaard door veranderingen in gevoeligheid voor diverse factoren, maar kan mogelijk wel verklaard worden doordat jongeren over de tijd gemiddeld aan minder risico- en meer beschermende factoren zijn blootgesteld, waarbij met name veranderingen in het gezinsdomein en alcoholgebruik van jongeren opvallen. In de opeenvolgende cohorten melden meer jongeren dat hun ouders weten van en toezicht houden op hun (vrijetijds)activiteiten (betrokkenheid, monitoren), en meer jongeren dat ze open zijn naar hun ouders over hun vrijetijdsactiviteiten. Dergelijke opvoedingsstijlen en de ervaren relatie tussen ouders en hun kinderen kunnen remmend werken in het vertonen van risicogedrag, zoals alcoholgebruik en ook delinquentie (Stattin \& Kerr, 2000). Ook is het denkbaar dat verminderd alcoholgebruik door jongeren zelf heeft bijgedragen aan de afname in delinquent gedrag, daar alcoholgebruik de kans op het plegen van delicten kan versterken. De ontwikkelingen wijzen op een in de tijd veranderende sociaal-culturele houding ten aanzien van risicogedrag, zowel bij jongeren als bij hun ouders. Een houding die risicogedrag meer afwijst. Deze veranderende houding kan in opeenvolgende cohorten mogelijk steeds meer jongeren hebben weerhouden van risicogedrag, waaronder ook delinquentie. De bevindingen geven aan dat om de daling in delinquentie te kunnen verklaren veranderingen die zich in de tijd min of meer gelijktijdig voordoen in predictoren van delinquent gedrag op meerdere leefdomeinen relevant zijn (Bronfenbrenner, 1977; Tonry, 2014).

Dat de associaties van risico- en beschermende factoren met delinquentie (gevoeligheid) consistent zijn over de tijd duidt erop dat dezelfde voorspellers voor delinquentie relevant blijven, zowel wat delinquentie in het algemeen als ernstige delinquentie betreft. Dit wijst erop dat de sociaalpsychologische verklaringen voor (ernstige) delinquentie over verschillende cohorten heen geldig blijven (zie ook Donovan e.a., 1999). De in het huidige onderzoek gebruikte risico- en beschermende factoren lijken een meer algemene verklaring te bieden voor zelfgerapporteerd delinquent gedrag in de adolescentie, zowel delinquentie in het algemeen als ernstige delinquentie, ongeacht de tijdsperiode waarin jongeren opgroeien en maatschappelijke veranderingen die zich daarin voordoen - hoewel we hierbij wel opmerken dat de metingen een periode van 'slechts' ongeveer tien jaar omvatten. De consistentie in voorspellers van delinquentie over de tijd in samenhang met de hoge respons in de metingen geeft niet alleen aanleiding om te stellen dat de resultaten gelden voor de grotere groep van Nederlandse jongeren, de stabiliteit van risico- en beschermende factoren over de tijd impliceert ook dat ('evidence-based') interventies gericht op deze factoren relevant blijven in de aanpak van jeugddelinquentie (vergelijk Donovan e.a., 1999).

Tot besluit, de jeugddelinquentie in Nederland daalt in het afgelopen decennium; dit betreft zowel de geregistreerde jeugdcriminaliteit als door jongeren zelf gerapporteerde delinquentie. Deze daling sluit aan bij de internationaal geconstateerde daling in de criminaliteit. Sommigen schrijven de daling in de algemene criminaliteit toe aan een enkele maatschappelijke ontwikkeling die in diverse landen min of meer gelijktijdig heeft plaatsgevonden, zoals toegenomen beveiliging of digitalisering. Anderen veronderstellen echter dat er sprake is van meerdere gelijktijdig optredende ontwikkelingen die hebben bijgedragen aan de daling in criminaliteit (Eisner, 2014; Pinker, 2011; Tonry, 2014; Zimring, 2007). De bevindingen in deze 
studie sluiten aan bij dit laatste perspectief. Ze laten zien dat de daling in jeugddelinquentie mogelijk kan worden verklaard door gelijktijdige veranderingen in blootstelling aan risico- en beschermende factoren op meerdere leefdomeinen. In vergelijking met 12- tot 18-jarigen uit 2005 rapporteerden jongeren in 2015 minder blootstelling aan risicofactoren, zoals alcoholgebruik of delinquente vrienden, en meer ervaringen met beschermende factoren, vooral binnen de gezinscontext, zoals een toename in de ervaren emotionele steun, betrokkenheid en monitoring door ouders. De ontwikkelingen wijzen op een in de tijd veranderende sociaal-culturele houding, zowel bij jongeren zelf als bij hun ouders, die in opeenvolgende cohorten steeds meer jongeren ervan weerhoudt risicogedrag te vertonen (zie ook De Looze e.a., 2014). Deze veranderende houding biedt daarmee een aanvullende verklaring voor de 'crime drop' onder jeugdigen.

\section{Literatuur}

Andersen, L.H., Tegner-Anker, A.S. \& Andersen, S.H. (2016). A formal decomposition of declining youth crime in Denmark. Demographic Research, 35, 1303-1316.

Beerthuizen, M.G.C.J., Weijters, G. \& Laan, A.M. van der (2017). The release of Grand Theft Auto V and registered juvenile crime in the Netherlands. European Journal of Criminology. doi: 10.1177/1477370817717070, 1-15.

Berghuis, A.C. \& Waard, J. de (2017). Verdampende jeugdcriminaliteit. Verklaringen van de internationale daling. Justitiële verkenningen, 43(1), 10-27.

Braga, A.A. \& Weisburd, D. (2010). Policing problem places. Oxford: Oxford University Press.

Bronfenbrenner, U. (1977). Toward an experimental ecology of human development. American Psychologist, 513-531.

Bronfenbrenner, U. \& Ceci, S. (1994). Nature-nurture reconceptualized in developmental perspective. A bioecological model. Psychological Review, 101, 568-586.

Brown, T.N., Schulenberg, J.E., Bachman, J.G., O’Malley, P.M. \& Johnston, L.D. (2001). Are risk and protective factors for substance use consistent across historical time? National data from the high school classes of 1976 through 1997. Prevention Science, 2, 29-43.

Caspi, A., Moffit, T.E., Silva, P.A., Stouthamer-Loeber, M., Krueger, R.F. \& Schmutte, P. (1994). Are some people crime-prone? Replications of the personality-crime relationship across countries, genders, races and methods. Criminology, 32, 163-195.

Coleman, J. (1990). Foundations of social theory. Harvard: Harvard University Press.

Dijk, J. van, Tseloni, A. \& Farrell, G. (2012). The international crime drop. New York: Palgrave Macmillan.

Donovan, J.E., Jessor, R. \& Costa, F.M. (1999). Adolescent problem drinking: stability of psychosocial and behavioral correlates across a generation. Journal of Studies on Alcohol, 60, 352-361.

Eisner, M. (2014). From swords to words: does macro-level change in self-control predict long-term variations in the level of homicide? Crime \& Justice, 43, 65-134.

Engelen, F., Roels, J. \& Heij, V. de (2015). Monitor Zelfgerapporteerde Jeugdcriminaliteit hoofdonderzoek 2015. Onderzoeksdocumentatie. Heerlen: CBS.

Eurostat (2016). Crime and criminal justice. Retrieved from http://ec.europa.eu/eurostat/ web/crime/database on 9 October 2017. 
Farrell, G., Tilley, N. \& Tseloni, A. (2014). Why the crime drop? Crime and Justice, 43, 421-490.

Farrington, D.P. \& Loeber, R. (2000). Some benefits of dichotomization in psychiatric and criminological research. Criminal Behavior and Mental Health, 10, 100-122.

Fletcher, A.C., Steinberg, L. \& Williams-Wheeler, M. (2004). Parental influences on adolescent problem behavior: revisiting Stattin and Kerr. Child Development, 75, 781-796.

Goodman, R. (1997). The Strengths and Difficulties Questionnaire: a research note. Journal of Child Psychology and Psychiatry, 38, 581-586.

Gould, E.D., Weinberg, B.A. \& Mustard, D.B. (2002). Crime rates and local labor market opportunities in the United States: 1979-1997. Review of Economics and Statistics, 84, 45-61.

Hoeve, M., Dubas, J.S., Eichelsheim, V., Laan, P.H. van der, Smeenk, W. \& Gerris, J.R.M. (2009). The relationship between parenting and delinquency: a meta-analysis. Journal of Abnormal Child Psychology, 37, 749-775.

Hoeve, M., Stams, G.J.J.M., Put, C. van der, Dubas, J.S., Laan, P.H. van der \& Gerris, J.R.M. (2012). A meta-analysis of attachment to parents and delinquency. Journal of Abnormal Child Psychology, 40, 771-785.

Jolliffe, D. \& Farrington, D.P. (2014). Self-reported offending: reliability and validity. In: G.J.N. Bruinsma \& D. Weisburd (eds.). Encyclopedia of criminology and criminal justice. New York: Springer, 4716-4723.

Keizer, R. \& Dykstra, P. (2013). Zorgende vaders. Demos, 29, 1-4.

Laan, A.M. van der \& Blom, M. (2006). Jeugddelinquentie: risico's en bescherming. Den Haag: Boom Juridische uitgevers.

Laan, A.M. van der \& Goudriaan, H. (2016). Ontwikkelingen in de jeugdcriminaliteit, 1997 tot 2015. Den Haag: WODC/CBS.

Laan, A.M. van der \& Weijters, G. (2015). Daling in de geregistreerde jeugdcriminaliteit. Enkele mogelijke verklaringen. Tijdschrift voor Criminologie, 57, 203-228.

Levitt, S.D. (2004). Understanding why crime fell in the 1990s: four factors that explain the decline and six that do not. Journal of Economic Perspectives, 18, 163-190.

Lochner, L. \& Moretti, E. (2004). The effect of education on crime. Evidence from prison inmates, arrests, and self-reports. American Economic Review, 94, 155-189.

Loeber, R., Slot, N.W. \& Stouthamer-Loeber, M. (2008). A cumulative developmental model of risk and promotive factors. In: R. Loeber, N.W. Slot, P.H. van der Laan \& M. Hoeve (eds.). Tomorrow's criminals. Farnhame: Ashgate, 133-161.

Looze, M. de, Vermeulen-Smit, E., Bogt, T. ter, Dorsselaer, S. van, Verdurmen, J., Schulten, I. e.a. (2014). Trends in alcohol-specific parenting practices and adolescent alcohol use between 2007 and 2011 in the Netherlands. International Journal of Drug Policy, 25, 133-141.

Maguin, E. \& Loeber, R. (1996). Academic performance and delinquency. Crime and Justice, $20,145-264$.

Markus, M.T., Lindhout, I.E., Boer, F., Hoogendijk, T.H.G. \& Arrindell, W.A. (2003). Factors of perceived parental rearing styles: the EMBU-C examined in a sample of Dutch primary school children. Personality and Individual Differences, 34, 503-519.

Monshouwer, K., Dorsselaer, S. van, Gorter, A., Verdurmen, J. \& Vollebergh, W. (2004). Jeugd en riskant gedrag. Kerngegevens uit het Peilstationonderzoek 2003. Utrecht: Trimbos-Instituut.

Patrick, M.E. \& Schulenberg, J.E. (2017). Prevalence and predictors of adolescent alcohol use and binge drinking in the United States. Alcohol Research, 35, 193-200.

Pietersma, S. \& Veenstra, R. (2004). Nederlandse vertaling Stattin en Kerr (2000) ouder-kind vragenlijst. The Trails-studies. Groningen: Universiteit Groningen (niet gepubliceerd). 
Pinker, S. (2011). The better angels of our nature. A history of violence and humanity. London: Penguin.

Piquero, A.R., Farrington, D.P. \& Blumstein, A. (2003). The criminal career paradigm. Crime \& Justice, 30, 359-505.

Pollard, J.A., Hawkins, J.D. \& Arthur, M.W. (1999). Risk and protection: are both necessary to understand diverse behavioral outcomes in adolescence? Social Work Research, 23, 145-159.

Roeder, O., Eisen, L.-B. \& Bowling, J. (2015). What caused the crime decline? New York: Brennan Centre for Justice.

Rokven, J., Weijters, G. \& Laan, A.M. van der (2017). Jeugddelinquentie in de virtuele wereld. Een nieuw type daders of mogelijkheden voor traditionele daders. Den Haag: WODC.

Roth, J.A., Koper, C.S. \& Daly, R.M. (2012). Understanding the 'Whys' behind juvenile crime trends. Retrieved from https://www.ojjdp.gov/ojstatbb/publications/StatBBAbstract. asp?BibID=271092 in May 2017.

Stattin, H. \& Kerr, M. (2000). Parental monitoring: a reinterpretation. Child Development, 71, 1072-1085.

Stoop, I.A.L. (2005). The hunt for the last respondent. Nonresponse in sample surveys. Den Haag/Utrecht: SCP/Universiteit Utrecht.

Stouthamer-Loeber, M., Loeber, R., Wei, E.H., Farrington, D.P. \& Wikstrom, P.O.H. (2002). Risk and promotive effects in the explanation of persistent serious delinquency in boys. Journal of Consulting and Clinical Psychology, 70, 111-123.

Tanner-Smith, E.E., Wilson, S.J. \& Lipsey, M.W. (2013). Risk factors and crime. In: F.T. Cullen \& P. Wilcox (eds.). The Oxford handbook of criminological theory. Oxford: Oxford University Press, 89-111.

Tcherni, M., Davies, A., Lopes, G. \& Lizotte, A. (2016). The dark figure of online property crime: is cyberspace hiding a crime wave? Justice Quarterly, 33, 890-911.

Tonry, M. (2014). Why crime rates are falling throughout the Western world. Crime \& Justice, $43,1-64$.

Veenstra, R., Lindenberg, S., Oldehinkel, A.J., De Winter, A.F. \& Ormel, J. (2006). Temperament, environment, and antisocial behavior in a population sample of preadolescent boys and girls. International Journal of Behavioral Development, 30, 422-432.

Verburg, I. (2011). Monitor Zelfgerapporteerde Jeugdcriminaliteit: steekproeftrekking, nonresponsanalyse en weging. Den Haag: CBS (niet gepubliceerd).

Vollaard, B. \& Koning, P. (2009). The effect of police on crime, disorder and victim precaution. International Review of Law and Economics, 29, 336-348.

Wallace, J.M. \& Muroff, J.R. (2002). Preventing substance abuse among African American children and youth: race differences in risk factor exposure and vulnerability. The Journal of Primary Prevention, 22, 235-261.

Weerman, F.C. (2017). Social media en smartphones als verklaring voor de daling in jeugdcriminaliteit? Justitiële verkenningen, 43(1), 71-87.

Weerman, F.C., Smeenk, W., Slotboom, A., Harland, P., Dijker, L. den, Bijleveld, C. e.a. (2003). De survey van het NSCR-schoolproject. Leiden: NSCR.

Weijters, G., Laan, A.M. van der \& Kessels, R.J. (2016). De overeenstemming tussen zelfgerapporteerde jeugdcriminaliteit en bij de politie bekende jeugdige verdachten. Den Haag: WODC.

Widenfelt, B. van, Goedhart, A., Treffers, P.D.A. \& Goodman, R. (2003). Dutch version of the Strengths and Difficulties Questionnaire (SDQ). European Child \& Adolescent Psychiatry, 12, 281-289.

Wong, T. (2012). Girl delinquency. Oisterwijk: BOXPress.

Zimring, F.E. (2007). The great American crime decline. Oxford: Oxford University Press. 


\title{
Bijlage 1 Overzicht zelfgerapporteerde delicten
}

\author{
Eerste vraag: Heb je weleens: \\ Indien 'ja', vervolgvraag: 'Hoe vaak heb je in de afgelopen 12 maanden:*
}

\section{Vernieling en openbare orde delicten}

... expres een auto of een ander voertuig beschadigd of vernield, bijvoorbeeld door te bekrassen of een ruit in te gooien?

... expres de woning van iemand beschadigd of vernield, bijvoorbeeld door een ruit in te gooien?

... expres iets in een bus, tram, metro of trein vernield?

... expres iets anders beschadigd of vernield dat niet van jou was?

... muren, trams, metro's, bussen en dergelijke beklad met pennen, stiften, een spuitbus of iets anders?

\section{Vermogensdelicten}

... in een winkel prijsjes verwisseld om iets voor minder geld mee te kunnen nemen?

... iets uit een winkel meegenomen zonder te betalen dat goedkoper of gelijk aan 10 euro was?

$\ldots$ iets uit een winkel meegenomen zonder te betalen dat duurder was dan 10 euro?

... iets uit je school of van je werkplek gestolen?

... een fiets of een scooter (brommer) gestolen?

... iets van de buitenkant van een auto of voertuig gestolen?

... iemands zakken gerold en bijvoorbeeld zijn of haar portemonnee, sleutels of mobiele telefoon gestolen?

... iets gekocht waarvan je wist of dacht dat het gestolen was, bijvoorbeeld cd's, een mobiele telefoon, kleding of iets dergelijks?

... iets verkocht waarvan je wist of dacht dat het gestolen was, bijvoorbeeld cd's, een mobiele telefoon, kleding of iets dergelijks?

... iets uit een afgesloten auto gestolen, bijvoorbeeld een radio/cd-speler, mobiele telefoon of andere spullen?

... ergens ingebroken, bijvoorbeeld in een huis, school, bouwkeet of iets dergelijks omdat je iets wilde stelen?

\section{Geweld of agressiedelicten}

... iemand bedreigd met de bedoeling hem/haar bang te maken?

... iemand expres geslagen en/of geschopt zonder dat die persoon volgens jou gewond is geraakt?

Heb je ooit weleens iemand expres zo geslagen en/of geschopt dat die persoon daardoor gewond is geraakt?

... iemand op straat bedreigd met de bedoeling iets van hem of haar te stelen?

... geweld gebruikt om iets van iemand te stelen, bijvoorbeeld een handtasje, een portemonnee of een mobiele telefoon?

... een wapen bij je, met de bedoeling jezelf te beschermen of voor het geval je bij een gevecht betrokken raakt?

... geprobeerd seks te hebben met iemand die dat niet wilde?

... expres iemand met een wapen verwond?

\section{Drugsdelicten}


... softdrugs zoals wiet of hasj verkocht?

... XTC (Ecstasy, MDMA), paddo's (magic mushrooms) of amfetamine verkocht?

... andere harddrugs zoals cocaine (coke of wit) of heroïne (horse, smack of bruin) verkocht?

* In het huidige onderzoek is gebruik gemaakt van de antwoorden op de afgelopen 12 maanden. 